\title{
Turning Points in Computer Education
}

\author{
Bill Davey ${ }^{1}$ and Kevin R. Parker ${ }^{2}$ \\ ${ }^{1}$ RMIT University, Melbourne Australia \\ bill. davey@mrit.edu.au \\ ${ }^{2}$ College of Business, Idaho State University, Pocatello USA \\ parkerkr@isu.edu
}

\begin{abstract}
This history of computers in education covers two continents. By analysing the experiences of two people a set of turning points in history is identified. These turning points are in the experienced history and so indicate the impact of changes on the citizens of two countries.
\end{abstract}

Keywords: Computers, education, history.

\section{Introduction}

One view of the history of computers and education starts with the use of computers like CSIRAC, used some educational purposes starting in November 1949 [1]. We can be certain that large scale roll outs of educational programs had been established by 1968 as, in that year, reports were being published regarding the success of the use of PLATO terminals [2-4]. Despite the certainty of facts supporting this view of history, questions remain: "How widespread were computers in education?" and "what were the real impacts on people's lives from the computer and when did they become real for the ordinary person?"

Trends in history can be seen by following the careers of giants and pioneers. Another view can be obtained by following the paths of those who are swept along by history. This paper examines the career of two information systems academics from either side of the Pacific, one Australian and one American. These two societies, which were responsible for producing the first computers and using them as educational aids, are considered to be at the forefront of computers in education. A narrative of these two lives shows trends and helps to identify the turning points in the impact of computing from the standpoint of interested bystanders. Rather than laying out the narrative in chronological order we capture the history of the two subjects in terms of the important stages of computers in their lives.

\section{Method}

To prepare this paper the two authors started with an initial brief: "what was the impact on our lives of information and communication technologies." This resulted in two narratives that were prepared independently, recounting the circumstances that each person thought of as significant. The narratives were then swapped and some 
content added, on each side of the Pacific, as a result of memory being stimulated by the other narrative. After some dialogue a set of themes was determined that captured the commonality between the narratives.

\section{High School}

There is almost a decade in age difference between the two authors. This age difference had its most profound effect during the authors' high school years. Those years, during the $60 \mathrm{~s}$ and $70 \mathrm{~s}$, coincided with an increased availability of computers. Thus, the narratives commence with their high school experiences to show the extent to which the change during that time period affected the average high school student.

The Australian attended high school in the 1960s before high school computing courses became available. Technology affected his life greatly. The launch of Sputnik in 1958 created an atmosphere of panic in the USA and Australia that was reflected in immense changes in the emphasis put on the sciences. American educators became convinced that the Soviets had been able to launch a satellite before the USA because of a superior education system. Intense efforts were devoted to improving the education system, particularly in the sciences, and they spread throughout the Western world. The Australian education system in 1964 saw the introduction of a new experiment-based physics course known as PSSC (Physical Science Study Committee) Physics. This meant that high school students in Australia were introduced to the idea that students could learn by exploring and understanding rather than by repetition. In this environment the Australian, an above average student, was swept into an interest in and love of the physical sciences. The Australian student had to drop subjects seen as not important to a university science course such as Latin, geography, and history. As an above average student he was directed away from commerce courses involving typing, bookkeeping, and office practices into the "important" subjects of English, pure and applied mathematics, physics, and chemistry. Contemporary history shows that computers were being distributed through the public service and some businesses at this time, but there was no mention of them in high schools.

The American attended high school in a small town in the mid-1970s. The local high school offered data processing courses taught by the vocational/technical education department. Vo/Tech, as it was called, also offered classes in automobile repair and other "blue collar" areas. Students who aspired to attend college were advised by school counsellors to steer clear of $\mathrm{Vo} / \mathrm{Tech}$ classes in order to take "more rigorous" courses. Therefore the American had no computing-related courses in high school. Fortunately his older sister-in-law got a job in data processing at the local junior college, and sometimes brought home a portable remote terminal and a primitive modem to demonstrate simple games or how the computer could generate drawings of the cartoon characters like Snoopy through the placement of alphanumeric characters. The American student was intrigued.

It can be said of both students that computers had not really affected their high school lives and formal study. It can also be said that the environment of their teenage years would predispose them to an interest in computers when they became more available. 


\section{University}

The Australian chose to attend the newly created Monash University in Victoria. At the time this University seemed to be well ahead of its time. They offered a physics course that included coverage of quantum mechanics, relativity, and the type of celestial mechanics related to space travel. This seemed greatly preferable to the more established Ivy League university in which physics still included the study of steam power. By coincidence this University was also committed totally to computerization. Before building had commenced on the University the Interim Council was interested in establishing computer resources at the new university. They believed that once it was operating the University should use the new computing devices for student record and enrolments. An extract from their minutes dated 21 March 1960 notes, "The Council strongly supported proposals that students' records and accounting be mechanized, as far as practicable, from the outset" [5].

This commitment had not extended to the first year classroom by the time our Australian attended classes in 1966. In the first year the statistics classes did involve the use of mechanical calculating machines. The user entered data by pushing keys and pulling a handle to make the machine calculate the answer. By second-year these machines included an electric motor that did away with the onerous task of pulling on the handle. In the third year computer programming classes became available. Behind these classes was a long (for a new University) history of solid work. Australian computer pioneers had brought computers into the University in 1962. The Monash history [5] records the following:

The 7000 word machine arrived on board ship in Melbourne in early 1962. Dr. Cliff Bellamy, then employed by Ferranti, worked with Professor Westfold and Dr. Sinclair to create a proposal for a joint computer installation at the University. The University would provide space for the temporary loan of the 7000 word Sirius, with two sets of Ferranti/Creed model 75 tape editing equipment in a room fitted with office furniture and telephones.

The Australian started with a class using the Ferranti and punched tape, requiring knowledge of Hollerith code and machine language. By his final year he was using IBM punch card machines to write programs in the user-friendly FORTRAN language. This revolution seemed like a paradise compared with the tedious "one chance" coding onto tape. On reflection the idea of typing cards in the early hours of the morning and having a one or two day turnaround before finding that a card had been placed out of order or a batch card was missing does not seem so pleasant. The point here is that in the time frame of a year or two the computing facilities had changed so much for the better that the student could see a rapid spiral of access that would make computers exciting for some time to come.

The American enrolled in the local junior college in 1977, the same college at which his sister-in-law had once worked. He was taking his general education courses prior to attending a university, and decided to pursue his interest in computers by taking a programming course offered by the data processing staff. The course taught the basics of programming using FORTRAN IV. Programs were written on special forms called coding sheets and then converted to punch cards using a keypunch 
machines with a typewriter-like keyboard. Each line of code required an individual punch card. Groups or "decks" of cards combined to form programs. Students submitted the program decks, generally followed by data cards to be read by the program, to a person working behind a counter in the computer room. Decks contained special Job Control Language cards to act as job separators so that an operator could stack several job decks in the card reader at the same time and be able to quickly separate the decks manually when he removed them from the stacker. After running a job the computer operator would return the card deck and any hardcopy output to the student or file it for later student pickup. He did not enjoy the course and decided that his interest in computers had been misplaced.

He then transferred to at the University of Texas at Austin in 1979. He started pursuing a degree in Chemical Engineering, but quickly found that he had little interest in that major. A friend talked him into taking a Pascal programming course, and this time the instructor was more experienced and a better communicator and the American thoroughly enjoyed the course and found that he had an affinity for programming and software development. As with his prior experience, punch cards were used for program submission. Unlike the much smaller junior college, however, wait times could be discouraging The university had multiple computer labs in various buildings across campus. Lines at keypunch machines and for deck submission were often so long that the American student would go to the labs at $3 \mathrm{AM}$ to reduce his wait time. The wait time did, however, teach the American the advantages of dedicating a significant effort to the problem-solving phase so that less time could be spent on the implementation phase, an approach that today's students fail to embrace.

The computer science curriculum was well established at that time, and the American took courses in Assembly Language Techniques, Programming Languages, Programming Applications and Practices, Data Structures, Database Management Systems, Numerical Techniques, Artificial Intelligence, and Computer Systems Architecture.

These stories demonstrate the second turning point, in which computers became available to the undergraduate. In both cases they are seen as a vehicle for executing computer programs and each person saw a large jump in ease of use that sparked an interest in becoming adept with the new technology.

\section{First Jobs}

The Australian's university education was financed through a government scholarship that required him to teach in the school system for three years. By 1970, when he first commenced full time work, the baby boom was well under way in Australia as it was everywhere else in the post war world. The number of new high school teachers was far below the numbers required by the enormous population of high school students. Because the Australian was a new teacher he received a posting at a country high school. The Institute of Technology was short of mathematics teachers in that country town and the young teacher found himself responsible for all the senior mathematics and physics classes, as well as a part-time job teaching engineering mathematics at the Institute. Since this was before an awareness of the importance of balancing work and home life, the new teacher also decided to undertake a postgraduate course in computing at the Institute. By coincidence and enormous luck the local Institute 
computing degrees were run by the very famous "Westy" Williams, another of the pioneers of Australian computing. This meant that the courses undertaken involved the very most recent computing products. The FORTRAN IV and COBOL languages were featured in the course.

At the same time Monash University had developed a computer system for schools called the MONECS system. This allowed high school students to create programs in FORTRAN using punch cards, post them to Monash, and get a printout explaining the coding errors within a few days. This was very frustrating for teachers and so the local institute was approached for alternatives. A small hand-operated card punch machine was purchased for a mere thousand dollars (about 6 months' salary for a beginning teacher) that allowed cards to be reliably punched and fit into the local Institute computer. This use of computers, to teach programming using punched cards, was a fairly common practice in Australian high schools. It was not until 1981 that a computer-related subject, Computer Science, became an accredited University entrance course [6]. By that time the Australian had been appointed as a curriculum consultant and was involved in managing this course.

The American had a variety of computing-related summer jobs while attending college. Two summers before graduation he worked as an Assistant Operator/Programmer at his former junior college, performing daily computer operations like routine backups, and also evaluated and upgraded various in-house software packages. Prior to his final year of college he worked as Systems Assistant at Conoco, Inc. in his home town modifying and upgrading existing software packages and participating in the analysis and design of new software. Upon graduation in the early 1980s he was hired full time at Conoco as a Programmer and within a year was promoted to Programmer/Analyst. His first job was to participate in the conversion from an IBM 1800 to a DEC PDP 11/34, including the design of replacement software. The programming language used was FORTRAN 77. It was during that conversion that he learned the importance of thorough documentation for maintainability and modifiability. He was responsible for various development projects including production control software, system interface packages, and report generation packages. As one of two on-site programmer/analysts he performed half of all systems development activities including software analysis, design, implementation, testing, and maintenance.

Thus, the second turning point was the recognition that computers were available more widely than in a University as a massive investment. They could be used to teach in high school as well as to enhance business efficiency. Computers were still seen from a programming perspective, but that perspective had shifted to programming with a purpose, not just as a kind of mathematical puzzle.

\section{Microcomputers}

The next stage in life is not characterized by normal progression but by the intrusion of a new technology. The first Intel-based microcomputer was released in November 1971 with the first Apple microcomputer arriving in 1976.

By 1975 the Australian teacher was a new father and had been selected as a curriculum consultant in mathematics. This entailed teaching part-time and travelling to other schools part-time to talk to teachers about the latest advances in mathematics 
education. Because of his history of teaching computing in schools the teacher was encouraged to apply for a grant to obtain one of the new microcomputers coming out of America from the Apple Corporation. The grant application was successful and, in his capacity as a member of the secondary math committee, the teacher travelled around Victoria demonstrating how the computer could be used in schools. By 1980 the school in which he was teaching had installed two microcomputer labs, a university entrance subject was available in computer science, and the whole idea of a twoday gap between writing a program and seeing the results was difficult to imagine. By 1989 when the Australian moved to the university sector the prevailing computing equipment was dumb terminals attached to a mainframe computer. Within two years of commencing that appointment almost all of the undergraduate computing was done on microcomputers. By 1991 the degree program in which he taught was called "Information Systems" and involved some programming, but included also the new disciplines of systems analysis and design, usability, and web delivery. The computer was no longer studied for its own sake, but as a tool for business purposes.

The American took a similar path. While working as a programmer/analyst in early 1984, two local higher educational institutions, his old junior college and a local private university, enlisted his aid to teach programming courses at night. At one institution he taught Pascal on a DEC minicomputer, and at the other taught Pascal on Apple microcomputers. He did this for a year, and then he accepted a full time position at the junior college as a computer science instructor. He was also placed in charge of the relatively new microcomputer lab, which had a conglomeration of IBM, Apple, Radio Shack, and other brands of microcomputers. In addition to teaching the usual courses dealing with fundamental computer science and information systems concepts, programming languages and techniques, and advanced data structures, he also taught microcomputer operating systems and usage, and developed the first courses in using spreadsheets (VisiCalc, then Lotus 1-2-3), word processing (WordStar, followed by WordPerfect), and databases (various versions of dBase by Ashton-Tate).

Less than four years later he then decided that he needed to pursue an advanced degree, and returned to college for a Master's degree in Computer Science (1991) and a doctorate in Information Systems (1995). He has been teaching Information Systems at the university level since graduation.

The microcomputer enabled interactive computing for everyone. Interactive languages and development environments were first seen as a better place for people to learn programming, but rapidly a wider view of the computer emerged. Information Systems had become more central than the hardware itself. Microcomputer applications like word processing, spreadsheet, and database software became essential components of most businesses. Both narratives see this change as being due to the sudden impact of personal computers with their enormous power/price advantages over time share systems.

\section{Using a Computer}

The final turning point grows out of the ubiquity of the microprocessor and the creation of the Internet. One could claim that the Internet started in September 1969 when the first host computer was connected at UCLA. It could also be argued that the 
historically significant event was the creation of ARPANET at the end of 1969 or the first email application in 1972 or the transition to TCP/IP on January 1, 1983 [7]. Our measure of significance is the point at which the Internet became readily available to our two boys.

The Australian first found telecommunications useful for completing a graduate diploma in computing by external studies. Using an acoustic coupler and Kermit software on his Apple II the degree was completed late at night from this office in 1982. USENET had been a fascination since completing a postgraduate education degree in 1978, where the thesis was written on a DEC10 using the QEDIT program written by Queensland University. The facilities showed him the potential of the global network, but it was only when a microcomputer was available at home, with email and USENET, that it became a daily tool for communication. Finally the modern era of asynchronous communications with everyone in the world was ushered in as he took a leading role in the first Pan Pacific computing conference in 1985. This involved academics and others from around the world communicating exclusively by email.

For the American, widespread use of the Internet and World Wide Web started during his final year of graduate school (1995) and intensified during his subsequent university appointment. His early exposure involved protocols like telnet, Kermit, and Gopher, and search tools like Veronica. After graduating he started using Mosaic to access the World Wide Web, but quickly switched to the "new" browser, Netscape Navigator. His first e-mail client was Pine, but he switched to Eudora. Because of his ongoing affiliation with educational institutions he generally had free Internet access and never had to use any of the online services like CompuServe or America Online. At that time the popular search engines included Yahoo!, Infoseek, Excite, and Hotbot. His first capitulation to using the Windows operating system came with the advent of Windows for Workgroups. He developed his first commercial web site in 1998.

\section{A Timeline (Results)}

The twin narratives can be summarised by the headings we have used here, but a broader picture is obtained by comparing the individual histories with recognised events during the timeframe. In Table 1 below "recognised" historical events have been selected from the Computer History Museum timeline [8]. These show that events early in the history of computing did not always enter the consciousness of the ordinary person, but later events occurred only a short time before impacting the lives of the two subjects.

Table 1. Selected highlights from the narrative compared with highlights from the Computer History Museum

\begin{tabular}{|c|c|c|}
\hline Year & Selected highlights & Aussie and American Highlights \\
\hline 1941 & Z3 built built by Konrad Zuse & \\
\hline 1944 & Harvard Mark 1 and Colossus & \\
\hline
\end{tabular}


Table 1. (Continued)

\begin{tabular}{|c|c|c|}
\hline 1945 & $\begin{array}{l}\text { Von Neuman report on EDVAC, } \\
\text { first BUG reported by Grace hopper }\end{array}$ & \\
\hline 1946 & $\begin{array}{l}\text { ENIAC built, inspiring EDSAC, } \\
\text { BINAC, IAS, AVIDAC }\end{array}$ & \\
\hline 1947 & Transistor tested & \\
\hline 1949 & EDSAC built & \\
\hline 1951 & $\begin{array}{l}\text { UNIVAC in USA, LEO in UK, first } \\
\text { commercial computers }\end{array}$ & \\
\hline 1952 & $\begin{array}{l}\text { Grace Hopper first compiler, IBM } \\
\text { releases IBM726 magnetic storage }\end{array}$ & \\
\hline 1955 & $\begin{array}{l}\text { First transistorised computer, } \\
\text { TRADIC, at Bell Labs }\end{array}$ & \\
\hline 1957 & $\begin{array}{l}\text { FORTRAN, DEC corporation and } \\
\text { Sperry Rand created }\end{array}$ & \\
\hline 1960 & LISP and Quicksort released & $\begin{array}{l}\text { Aussie starts High School - no } \\
\text { computing. }\end{array}$ \\
\hline 1961 & IBM has $81 \%$ of computer market & \\
\hline 1966 & $\begin{array}{l}\text { HP } 2115 \text { released with BASIC, } \\
\text { ALGOL and FORTRAN }\end{array}$ & $\begin{array}{l}\text { Aussie starts University - } \\
\text { FORTRAN Programming }\end{array}$ \\
\hline 1969 & RS232 protocol and UNIX released & \\
\hline 1970 & $\begin{array}{l}\text { Xerox PARC opened, ARPANET } \\
\text { created }\end{array}$ & $\begin{array}{l}\text { Aussie teaches FORTRAN in High } \\
\text { School using punched cards in first } \\
\text { year of teaching. Enrols in graduate } \\
\text { computer course }\end{array}$ \\
\hline 1971 & $\begin{array}{l}\text { First Intel microprocessor, first } \\
\text { email }\end{array}$ & \\
\hline 1972 & 8008 processor made & \\
\hline 1973 & $\begin{array}{l}\text { Ethernet released and first personal } \\
\text { computer not in a kit (Micral) }\end{array}$ & \\
\hline 1974 & Mouse invented by Xerox & \\
\hline 1975 & $\begin{array}{l}\text { Bill Gates and Paul Allen license } \\
\text { BASIC as the language for the } \\
\text { Altair } 8800\end{array}$ & $\begin{array}{l}\text { American starts High School, DP } \\
\text { classes seen as "shop" }\end{array}$ \\
\hline
\end{tabular}


Table 1. (Continued)

\begin{tabular}{|c|c|c|}
\hline 1977 & $\begin{array}{l}\text { TRS 80, Commodore PET, Apple } \\
\text { II, Atari released }\end{array}$ & $\begin{array}{l}\text { American in Junior College. } \\
\text { Hated FORTRAN IV Classes }\end{array}$ \\
\hline 1978 & $\begin{array}{l}\text { Vax } 11 / 780 \text { and 51/4 inch floppies } \\
\text { released }\end{array}$ & $\begin{array}{l}\text { Aussie obtains Apple II for } \\
\text { demonstration }\end{array}$ \\
\hline 1979 & $\begin{array}{l}\text { USENET, Visicalc and Motorola } \\
68000 \text { released }\end{array}$ & $\begin{array}{l}\text { American changes to U Texas and } \\
\text { loves Pascal, pursues computer } \\
\text { science degree }\end{array}$ \\
\hline 1980 & $\begin{array}{l}\text { First hard disk for personal } \\
\text { computers from Seagate }\end{array}$ & $\begin{array}{l}\text { Aussie buys Apple II for home, } \\
\text { first PC lab of Apple II in school }\end{array}$ \\
\hline 1981 & $\begin{array}{l}\text { First IBM PC with MS-DOS, } \\
\text { Osborne portable computer } 3.5 \\
\text { inch disks }\end{array}$ & \\
\hline 1982 & Commodore 64, Lotus 123 & $\begin{array}{l}\text { Aussie uses USENET and email; } \\
\text { American graduates and works for } \\
\text { Conoco as FORTRAN } 77 \\
\text { programmer/analyst }\end{array}$ \\
\hline 1983 & $\begin{array}{l}\text { TCP/IP, Apple Lisa, Compac PC } \\
\text { clone }\end{array}$ & \\
\hline 1984 & Apple Mac, IBM PC AT & $\begin{array}{l}\text { Aussie school changes to IBM } \\
\text { PC, American part time teaching }\end{array}$ \\
\hline 1985 & & $\begin{array}{l}\text { American becomes full time } \\
\text { college computer science } \\
\text { instructor. Lab of PCs }\end{array}$ \\
\hline 1986 & & $\begin{array}{l}\text { Aussie organises conferences in } \\
\text { computing using email and } \\
\text { USENET }\end{array}$ \\
\hline 1991 & Linux & $\begin{array}{l}\text { American completes Masters in } \\
\text { Comp Sci }\end{array}$ \\
\hline 1993 & $\begin{array}{l}\text { Mosaic web browser released for } \\
\text { UNIX, Mac, Windows, Amiga } \\
\text { versions in } 1994\end{array}$ & \\
\hline 1994 & Yahoo founded & \\
\hline 1995 & & $\begin{array}{l}\text { American completes PhD in } \\
\text { Information Systems. First use of } \\
\text { WWW }\end{array}$ \\
\hline
\end{tabular}




\section{Conclusion}

By examining the critical points in the life history of these two people we see something of the way in which computing history is reflected through the lives of the ordinary person.

The rise of the computer took many years. Because computers were initially available only to governments as defence equipment, both the Australian and American had limited or no exposure to computers in high school. While the Australian experienced the introduction and spread of computers as a university undergraduate student, the American arrived on the scene at a time when university computers were relatively commonplace. In their first jobs they saw the proliferation of computers beyond the academic world, and with the arrival of microcomputers witnessed the eventual ubiquity of computers throughout society. Many of these advances in computing were invisible to the ordinary person.

Their experience shows that exposure to computers often begins in our educational system. The resultant familiarity with computers and software is then propagated beyond the classroom and eventually extends to the population in general. These dual narratives reveal three turning points:

- $\quad$ from ignorance of the computer to seeing it as a vehicle for executing programs

- from an interesting curiosity to a readily available tool

- from a tool to being ubiquitous device designed to support complex software.

The advent of sophisticated smart phones may mark the convergence between the wireless handheld and the PC Markets, changing the landscape of computing yet again [9]. While computers have evolved from being unattainable, to being a curiosity in the realm of hobbyists, to being commonplace and mundane, to the verge of becoming passé, the field of computing will continue to thrive as newer types of hardware and software are required to support this age of enhanced connectivity.

\section{References}

1. Doornbusch, P.: Computer Sound Synthesis in 1951: The Music of CSIRAC. Computer Music Journal 28, 10-25 (2004)

2. Blitzer, D.L., Skaperdas, D.: Plato IV - An economically viable large-scale computer-based education system. In: National Electronics Conference (1968)

3. Smith, S., Sherwood, B.: Educational uses of the PLATO computer system. Science 192, 344-352 (1976)

4. Plato Learning: History of Plato Learning, vol. 2004. Plato Learning Inc. (2004)

5. Monash University: Monash University's First Computer (2009)

6. Tatnall, A.: Curriculum Cycles in the History of Information Systems in Australia. Heidelberg Press, Melbourne (2006)

7. Leiner, B.M., Cerf, V.G., Clark, D.D., Kahn, R.E., Kleinrock, L., Lynch, D.C., Postel, J., Roberts, L.G., Wolff, S.: A Brief History of the Internet. ACM SIGCOMM Computer Communication Review 39, 22-31 (2009)

8. Computer History Museum, California, vol. 2010 (2010)

9. Knowledge@Wharton. As Smartphones Proliferate, Will One Company Emerge as the Clear Market Winner? (2009),

http: / / www. whartonsp. com/articles/article. aspx?p=1352785 